\section{Expansion of Glass by Heat}

THE reproduction in your "Physical Notes" (NATURE, vol. xxii. p. 157) of Mr. R. H. Ridout's neat experiment for illus trating the "Expansion of Glass by Heat" (Phil. Mag. for June, I880), recalls to mind an equally striking method of exhibiting this property of glass to a class of students in physics. Select a straight glass tube 50 or 60 centimetres in length and $\mathbf{I}$ or 2 centimetres in diameter. Place it transversely in front of a fire, in a horizontal position, properly supported near its two cnds on two horizontally-adjusted rods of hard smooth wood of about the same diameter as the tube ; the glass tube will gradually roll towards the fire. Now let the supporting rods be transferred to either side of the centre of the tube, so as to support it near its middle; the tube will now gradnally roll from the fire.

It is scarcely recessary to remind the reader that the greater dilatation of the glass on the side of the tube which is nearer the fire renders it curved, with the convexity next to the source of heat, so that, when supported near the ends, the falling of the central parts of the curved tube rolls it towards the fire; but when supported near the middle the falling of the ends of the similarly curved tube rolls it from the fire. These experiments, it is evident, succeed better when the cold tube is first adjusted near the fire than when it has been so long exposed to the action of the heat as to have become heated throughout its mass.

It seems that about the year I 740 this behaviour of glass tubes under similar conditions was noticed by $\mathrm{Mr}$. C. Orme, of Ashby de la Zouch, while heating some barometer tubes. The Rev. Granville Wheler, who carefully verified the experiments of $\mathrm{Mr}$. Orme, very correctly ascribes the phenomena to the distortion of the tube due to the action of heat (vide Phil. Trans., No. 476 ; also Edinburgh Encyclopidia, Ist Am. ed., I832, vol. ix., article "Glass," p. 773). Nevertheless in the United States this behaviour of glass tubes, when placed before a fire, has been frequently classed among the unexplained mysteries of glass I As recently as I $865 \mathrm{Mr}$. Deming Jarves, of Boston, in his little volume entitled "Reminiscences of Glass-Making," p, Io (2nd ed., N.Y., I865), refers to the phenomena, but with not one word of explanation. In fact not long ago some of our semiscientific journals characterised these phenomena as mysterious and inexplicab'e. Hence I have for the last twenty or thirty years employed such experiments, not only as exhibiting visible manifestations of the expansion of glass, but also as affording an instructive and significant illustration of how completely the most obvious mechanical results may be overlooked or obscured under the inspiration of the propensity to seek for the marvellous in nature!

Berkeley, California, July 8

\section{Fascination in Man}

HAVING frequently seen it stated in popular works on natural history as well as in some books of travels (chiefly Australian) that certain snakes possessed the power of so fascinating, with their gaze, birds and other creatures as to be able to seize upon and devour them without any difficulty, I am induced to inquire it such a power is peculiar to the serpent tribe or not, and inci dentally to ask if any instances of its influence or extension can be traced, up the scale of creation, to man himself. Being of opinion that such is the case, while it has occurred to me that many of the fatal accidents that occur in the streets of large cities, such a: London, \&c., might be ascribed to some such anency or sensation, I am induced to call attention to the circumstance in these pages, and to submit the following as my own personal contributions towards the inquiry :-

Describing certain incidents of the siege of Gibraltar, Drinkwater says, "History," p. 75, that "on the 9th Licut. Lowe . . lost his leg by a strot on the slope of the hill under the castle," and the italics are mine throughout. "He saw the shot before the fatal effect, but was fascinated to the spot. This sudden arrest of the faculties was not uncommon. Several instances occurred to my own observation where men totally free have had their senses so engraged by a shell in its descent that, though sensible of their danger, even so far as to cry for assistance, they have been immediately fixed to the place. But what is more remarkable, these men have so instantaneously recovered themselves on its fall to the ground as to remove to a place of safety before the shell burst."

Alluding to the first casualty that occurred at Cawnpore during the siege of the entrenchment there in 1857 , Mowbray Thom- son says ("The Story of Cawnpore," p. 66) that " several of us saw the ball bounding towards us, and he (McGuire) evidently Saw it, but, like many others whom 1 saw fall at different times, he seemed fascinated to the spot" ; and an old and now deceased departmental friend, who went through the whole Crimean campaign, assured me that he was once transfixed (fascinated, he called it) after this fashion in presence of a shell that he saw issuing from Sebastopol, and whose every gyration in the air he could count. Other military friends have discussed the point with me in this same wise, and I think there is some allusion $t$ it in one or other of the works of Larry, Guthrie, Ballingall, or others of that ilk.

Warrington

\section{Monkeys in the West Indies}

IN consequence of my removal from the West Indies to the West Coast of Africa, and of illness since my arrival here, $I$ have not until now had time to read in the back numbers of NATURE the controversy on the subject of "Monkeys in the West Indies," which, it may be said, I created by my communication in NATURE, vol xxi. p. I3I. I trust, therefore, I now may be permitted to reappear on the scene and to sum up my case.

In my communication I quoted, from Prof. Mivart's lecture on "Tails," an extract which appeared in your columns (NATuRF, vol, xx, p. 510), viz.: "Monkeys are scattered over almost all the warmest parts of the earth save the West Indies, Madagascar, New Guinea, and Australia," and I added, with the utmost respect for Prof. Mivart, that the above statement was not "quite correct," adducing as proof the fact that 'they were found in St. Kitts, Nevis, and Trinidad. Mr. Sclater, F.R.S., the distinguished zoologist, answered my letter (NATURE, vol, xxi. p. 153), explaining that Prof. Mivart was correct in his statement; that the monkeys of St. Kitts were not "indigenous" to that island, and that Trinidad originally was part of the mainland of South America. Mr. Sclater said nothing about the Nevis monkey. Dr. Imray of Dominica followed with a quotation from Père Labat (NATURE, vol. xxi. p. 37I), and as regards St. Kitts and Trinidad, the monkey question was closed.

But it subsequently came to my knowledge, throngh hearsay evidence, that monkeys existed in large numbers in Grenada, one of the Windward group of islands, although travellers and historians from the time of Père du Tertre to that' of Bryan Edwards seemed to be ignorant of the fact. As I had left the West Indies when I obtained this information, I at once called Dr. Imray's attention to it, begging him to ascertain its accuracy and then to communicate with NATURE. Dr. Imray has done so (NATURE, vol, xxii. p. 77), and, by a curious coincidence, his letter appears in the same number in which a Grenada correspondent, signing himself D. G. G., charges me with being "quite as much in error as Prof. Mivart," and makes me say that "the only islands in the West Indies where monkeys are to be found are St. Christopher [i.e., St. Kitts] and Nevis." The italics are my own, but I think D. G. G. should at least be careful to quote accurately.

I have no wish to trespass further on your valuable space. What I desired to show and what I have shown is that monkeys ao exist in many of the West. India Islands, and that, although nearly four hundred years have passed away since the discovery of the islands, their natural history. is still very imperfectly known. And yet these islands are within easy steaming distance from England; they are inhabited by people whose kindness and hospitality to visitors are proverbial. Their mountains afford all the varieties of healthy climate, and for the botanist, the geologist, the entomologist, and the man of science generally, there are few, if any, richer fields of instruction and enjoyment.

Government House, Cape Coast Castle, Edmund WatT Gold Coast, July 3

\section{Utricularia}

CAN any of the readers of NATURE inform me whether the sharp clicking noises produced on removing Utriculariz from the water (particularly for the first time) have been noticed or described? I have not succeeded in determining the species, as the plants are not yet in flower.

R.I.E. College, Cooper's Hill, July 30 